członkowskich. Także ze strony instytucji Wspólnoty został on poddany niemałej krytyce. Wynikiem obrad IGC było wzmocnienie w systemie, w porównaniu do pierwotnych postanowień, państw członkowskich. Jednakże, zgodnie z pewną filozofią integracji, jak wskazuje Autor, zostają wzmocnione oba pierwiastki, zarówno ponadnarodowy, jak i międzyrządowy.

Bardzo silną stroną książki jest szczegółowy opis: poszczególnych wydarzeń, negocjacji międzyrządowych, proponowanych zmian prawnych. Jest to jeden z czynników wpływających na obszerność tej monografii. To jednak powoduje, że książka dla osób słabiej zorientowanych w temacie może być trudna w odbiorze. Znaczna dbałość o szczegóły nie ustrzegła jednak Autora od niejasnych tez, czy nawet błędów. Są to oczywiście pojedyncze przypadki, ale aby nie pozostać gołosłownym, podam choćby przykład częstego określania państw, które jeszcze nie przyjęły euro, jako państw nie należących do Unii Gospodarczej i Walutowej. Temat podjęty przez Janusza Węca, jest bez wątpienia bardzo ciekawym zagadnieniem. Sposób jego zaprezentowania jest bardzo rozbudowany. Jednakże pewien niedosyt pozostawia brak wniosków wykraczających poza stwierdzenie, iż każda reforma przynosiła wzmocnienie zarówno elementów ponadnarodowych, jak i międzyrządowych. Także zakończenie nie wypełnia tych funkcji, gdyż w praktyce jest streszczeniem książki, ze wskazaniem najważniejszych elementów w rozwoju systemu instytucjonalnego Unii Europejskiej.

ADAM JASKULSKI

Poznań

\title{
Andrzej Podraza, Unia Europejska w procesie reform traktatowych, Wydawnictwo Katolickiego Uniwersytetu Lubelskiego, Lublin 2007, ss. 708.
}

Książka Andrzeja Podrazy, która z założenia jest pracą habilitacyjną wpisuje się do kanonu publikacji wydanych w Polsce po 2000 roku, opisujących reformy w Unii Europejskiej w oparciu o analizę Traktatu Ustanawiającego Konstytucję dla Europy. Traktat ten, mimo tego, że nie wszedł w życie ze względu na niedokończenie procedury ratyfikacyjnej określonej w art. 48 Traktatu o Unii Europejskiej jest dla wielu badaczy z Polski i zza granicy traktatem wyznaczającym granicę pomiędzy nowym i starym podejściem do badania Unii Europejskiej i procesu integracji europejskiej. Jego rzetelna analiza pozwala na zbadanie w pełni dorobku integracyjnego oraz na tej podstawie na dookreślenie kierunków rozwoju Unii Europejskiej, chociażby w kontekście Traktatu Lizbońskiego. Autor dostrzega te dwie optyki, i przedstawioną do recenzji analizą stara się do nich nawiązać.

W bogatym w treść wstępie, Podraza decyduje się na przypomnienie i uzupełnienie siatki pojęć, którymi posługuje się w książce. Stąd też konieczne z punktu widzenia tematu pracy wyjaśnienie reformy traktatowej i pozatraktatowej, których cel jest rozumiany jako ,,[...] rewizja rozwiązań określonych w Traktatach, na mocy których funkcjonują Unia Europejska oraz Wspólnoty Europejskie. Jako [...] proces, w którym wprowadza się zarówno formalne jak i nieformalne innowacje w ramach konstytucyjnych, w których działają instytucje Unii Europejskiej”. . Opisywana reforma traktatowa z tego punktu widzenia „Bazuje na przekonaniu, że siłą sprawczą w reformie traktatowej są przede wszystkim państwa narodowe, bo ostatecznie to one decydują o zakresie i tempie integracji europejskiej"2. Wstęp ubogaca refleksja teoretyczna na

1 A. Podraza, Unia Europejska w procesie reform traktatowych, Wydawnictwo KUL, Lublin 2007 , s. 18.

2 Ibidem, s. 21. 
temat integracji europejskiej, w której to Autor odwołuje się do klasycznego podziału na podejście międzyrządowe z realizmem i liberalnym intergovermentalizmem, oraz podejście ponadnarodowe - neofunkcjonalizm. Przywołanie tych dwóch podejść badawczych jest istotne z punktu widzenia poruszanej tematyki. Odpowiada bowiem na dwa scenariusze rozwoju Unii Europejskiej i pozwala na skonstruowanie tez pracy. Sam Autor przekonuje, że „znaczenie dla wiedzy o integracji europejskiej ma ujmowanie reform traktatowych w kategoriach procesu, w którym dużą rolę ogrywają okresy między Konferencjami Międzyrządowymi"’3. Andrzej Podraza stawia sześć tez do określonego tytułem książki pola badawczego:

1. Ostatecznie państwa członkowskie decydują o kształcie Unii Europejskiej, o generalnych ramach, w których zachodzi proces integracji europejskiej.

2. Reformy w mniejszym stopniu dotyczą projektów gospodarczych, lecz głównie kwestii politycznych, instytucjonalnych i prawnych.

3. Głównym motywem działań podejmowanych przez państwa jest maksymalizacja własnej pozycji w Unii Europejskiej i dążenie do ochrony własnych interesów.

4. Rola instytucji ponadnarodowych w procesie reform traktatowych ma charakter pomocniczy - kształtują agendę i identyfikują możliwe rozwiązania.

5. Zwoływanie kolejnych Konferencji Międzyrządowych wynika z niemożności osiagnięcia rzeczywistego consensu, gdyż brak jest zgody co do ostatecznego modelu integracji europejskiej ${ }^{4}$.

Tak sformułowane tezy, pokazują perspektywę badawczą Autora, która zasadza się w teorii i praktyce podejścia międzyrządowego i nijak się ma do postmodernistycznych teorii opisujących państwo, organizacje międzynarodowe i decydentów politycznych, skłonnych uznać względność instytucji organizujących życie obywateli, państw na arenie globalnej. Takie założenia pozwalają potwierdzić pesymizm niektórych badaczy integracji europejskiej, co do przyszłości Unii Europejskiej, jej kształtu, czy umacnianego modelu współpracy. To stałe napięcie między międzyrządowością Charlesa de Gaull'a (umacnianie pozycji Rady, a przez to przekształcanie Unii w klasyczną organizację międzyrządową) i ponadnarodowością Roberta Schumana czy Jeana Monneta (proces decyzyjny w ramach trójkąta instytucjonalnego ze wzrostem kompetencji poszczególnych jego elementów, i opierający się, w dużym uproszczeniu ujmując, na rozwiązaniach elitystycznych bez udziału, czy też przy ograniczonym udziale, obywateli państw członkowskich UE).

W pierwszym rozdziale swej pracy Autor wskazuje na uwarunkowania procesu reform traktatowych, analizując proces poszerzania Unii, proces demokratyzacji Unii i określenie relacji pomiędzy Unią a państwami członkowskimi oraz obywatelami, zwiększanie międzynarodowej pozycji tej organizacji oraz proces konstytucjonalizacji i dookreślenie finalite politique Unii. Źródeł refleksu nad przyszłością, szuka również w Traktatach poprzedzających obrady Konwentu Europejskiego, tj. Traktat o Unii Europejskiej, Traktat Amsterdamski, czy też obowiązujący do dnia dzisiejszego Traktat Nicejski. Zauważa, że począwszy od Traktatu Amsterdamskiego reforma traktatowa dotyczyła w większej mierze niz dotychezas kwestii polityeznych oraz prawno-instytucjonalnych, a w mniejszym stopniu procesu integracji gospodarczej ${ }^{5}$. Traktat Amsterdamski według Autora wyznacza jeszcze jedną zasadniczą zmianę podejścia do określania motywów procesu reformy. Ich zmiana, w perspektywie rozszerzenia Unii o nowe państwa członkowskie, pokazuje wpływ na rodzaj dyskutowanych zagadnień i przesądza o decydującej roli państw członkowskich w obradach Konferencji Międzyrządowej. To uprawnia do konstatacji, że interes państw członkowskich, sposób jego prezentacji i zabiegania o przyjęcie rozwiązań

3 Ibidem, s. 27

4 Ibidem, s. 27-28.

5 Por. ibidem, s. 35 
dlań korzystnych, minimalizuje znaczenie instytucji ponadnarodowej - Komisji Europejskiej, która to, jak pokazuje również przebieg prac Konwentu, ogranicza się do wydawania agendy spotkań, i wspierania przyjętych rozwiązań. Co więcej, kierując się chęcią uelastycznienia integracji państwa członkowskie, zdaniem Podrazy, nieodpowiedzialnie wpisują w Traktat Amsterdamski, Nicejski i Konstytucyjny, zapisy o wzmocnionej współpracy. Nieodpowiedzialność sprowadza się do braku analizy ewentualnych skutków takich zapisów i przestawia integrację z modelu koherentnego na model zróżnicowanego rozwoju, co może być motywowane obawą przed tak bogatym w liczbę państw, kolejnym rozszerzeniem. Doskonałym tłem dla ilustracji powyższych wniosków jest opis zróżnicowanej (elastycznej) integracji, którego Autor dokonuje śledząc koncepcje Ralfa Dahrendorfa, Jacka Delorsa, Wesselsa, czy też Camerona. Rozdział drugi, to przedstawienie koncepcji integracji europejskiej w oparciu o analizę stanowisk wybranych państw członkowskich od połowy lat dziewięćdziesiątych. Analiza ta wydaje się jak najbardziej słuszna, gdyż jak wskazuje Autor, w kształtowanych hipotezach do pracy, starał się zrozumieć efekty pracy Konferencji Międzyrządowych, przez pryzmat prezentowanych stanowisk poszczególnych państw członkowskich. To ważne narzędzie pozwala na weryfikację hipotez, o podstawowej roli w procesach negocjacji, państw dużych i tych, które ustanowiły Wspólnoty Europejskie w latach 50. XX wieku ${ }^{6}$. Stąd też, czasami nużący, opis stanowisk Niemiec, Francji, Wielkiej Brytanii, Włoch, Holandii i Belgii. Wspomniana analiza jest interesująca, chociażby ze względu na dokonanie w jednym miejscu, porównania stanowisk koncepcji zróżnicowanej integracji i wykazanie czasami istotnych różnic w prezentowanych podejściach ${ }^{7}$. Dla nowych państw członkowskich czy też dla młodych naukowców, czy też studentów pochodzących z nowych państw ezłonkowskich, takie zestawienie może być pomocne, w zrozumieniu rozwiązań zaproponowanych w TKE, w dużej mierze powtórzonych w zapisach Traktatu Lizbońskiego. Rozdziały trzeci i czwarty, to klasyczna, rzetelna analiza, stanowisk negocjacyjnych, przyjętych rozwiązań instytucjonalnych i prawnych, wprowadzonych w życie Traktatem Amsterdamskim i Nicejskim. To dobra podstawa do rozpoczętej w rozdziale piątym analizy Traktatu Ustanawiającego Konstytucję dla Europy. To przedstawienie krok po kroku tak zwanego procesu postnicejskiego, prezentacja opinii Joschki Fischer'a, Lionela Jospin'a, Johannesa Rau'a czy też byłego premiera Belgii, autora książki pt. Stany Zjednoczone Europy, Guy'a Verhofstatda. W rozdziale tym Czytelnik znajdzie również opis raportów Grup Roboczych Konwentu Europejskiego, przebieg przyjmowania przez Konwent kolejnych części składowych Projektu Traktatu Ustanawiającego Konstytucję dla Europy oraz szczegółowy opis ważnych prezydencji: włoskiej i irlandzkiej, w której trakcie doszło do podpisania TKE. Część piąta rozdziału piątego, stanowić może pomoc w lekturze i komentarz do TKE. To swoiste podsumowanie znajdujące swój wyraz w poszczególnych artykułach i deklaracjach TKE. Słuszna jest refleksja Autora na temat konieczności dalszej reformy traktatowej, która nabiera szczególnego znaczenia w kontekście odrzucenia w referendum w Irlandii (2008) Traktatu Lizbońskiego, a mianowicie, konieczność dalszej reformy traktatowej istnieje chociażby ze względu na rozbieżność stanowisk negocjacyjnych poszczególnych państw członkowskich, co przekłada się na nietrwałość podjęty rozwiązań kompromisowych i stale umacniające się napięcie pomiędzy rozwiązaniami co do przyszłości Unii Europejskiej; ponadnarodowe-federacyjne czy też międzyrządowe.

Książka Andrzeja Podrazy, to ważna publikacja z zakresu reformy traktatowej Unii Europejskiej na polskim rynku wydawniczym. Podczas lektury książki uderza prostota języka, rzetelność naukowa wyrażająca się chociażby w bardzo szczegółowych opisach stanowisk, przedstawia-

6 Por. ibidem, s. 97 i n.

7 Por. opis każdego ze stanowisk prezentowanych przez Państwa Członkowskie kończy się podsumowaniem zawierającym przedstawienie wlaśnie tego zagadnienia. 
nych koncepcji i innych. Autor z pewnością wiele czasu poświęcił na zebranie tak doskonałego materiału badawczego w języku polskim, niemieckim, angielskim, francuskim. Poświęcony czas owocuje, dobra publikacją, o logicznym i przejrzystym toku myślowym, która czyta się swobodnie. Przeszkodą w lekturze materii mogą być zbyt obszerne opisy historyczne, które sprawiają, że czasami odnosi się wrażenie, że czyta się o rzeczach oczywistych. Autor jak i wydawca zadbali, aby najważniejsze informacje dotarły do czytelnika, bowiem konkluzje, hipotezy i tezy są wydrukowane wythuszczonym drukiem.

MIKOEAJ J. TOMASZYK

Poznań

\section{Tomasz Kubin, Polityczne implikacje wprowadzenia unii walutowej w Europie, Wydawnictwo Uniwersytetu Śląskiego, Katowice 2007, ss. 368.}

Dnia 1 stycznia 1999 roku na obszarze jedenastu spośród piętnastu krajów członkowskich Unii Europejskiej zaczęła funkcjonować unia walutowa ${ }^{1}$. Stała się ona ostatnim etapem integracji gospodarczej w Europie, zapoczątkowanej już w 1950 roku przez francuskiego ministra spraw zagranicznych Roberta Schumana, który zaproponował koordynację wydobycia strategicznych dla historii Europy surowców i utworzenie Europejskiej Wspólnoty Węgla i Stali. Kolejne podwaliny pod europejski proces integracji położono w 1958 roku, kiedy na mocy Traktatu Rzymskiego powołano Europejską Wspólnotę Gospodarczą. Organizacja składała się początkowo z sześciu państw członkowskich, jednak w przeciagu następnych lat ich liczba poszerzyła się do piętnastu. Mocą Traktatu z Maastricht podpisanego 7 lutego 1992 roku Europejska Wspólnota Gospodarcza została przekształcona we Wspólnotę Europejską, sam traktat powołał zaś do życia nową Unię Europejską. Wspólna polityka gospodarcza prowadzona w ramach państw członkowskich EWG została w nim poszerzona i uzupełniona o nowe kompetencje i zadania, spośród których kluczowym okazała się być Unia Gospodarcza i Walutowa.

Stworzenie Unii Gospodarezej i Walutowej stało się jednym z najważniejszych wydarzeń w historii kontynentu europejskiego. Oto z początkiem 2002 roku dwanaście krajów członkowskich Unii Europejskiej zrezygnowało z własnej waluty, celem połączenia wspólnym pieniądzem swoich gospodarek. I choć historia samego euro jest krótka, proces który doprowadził do jego wprowadzenia rozpoczął się wiele lat wcześniej.

Zagadnienie wspólnej waluty stało się obszarem zainteresowania Tomasza Kubina, który postanowił opisać jej historię i teraźniejszość w pracy Polityczne implikacje wprowadzenia unii walutowej w Europie.

Omawiana książka została podzielona na sześć rozdziałów, wstęp i zakończenie, których treść uzupełniona została wykazem stosowanych w dziele skrótów, bibliografią oraz sporządzonym w języku angielskim i niemieckim podsumowaniem.

W pełniącym rolę wprowadzenia rozdziale I Autor przedstawia system powiązań, jaki charakteryzuje polityczną i ekonomiczną integrację Europy. Ta część pracy podkreśla, że UGiW nie jest jedynie kolejnym, gospodarezym etapem w drodze do pełnej integracji państw - przeciwnie, przedstawione w rozdziale opinie uznanych autorów wskazują jak silne jest połączenie ekonomii i polityki, zarówno w dziedzinie integracji walutowej, jak i integracji europejskiej w ogóle.

1 Dwunastym czlonkiem UGiW zostala Grecja 1 stycznia 2001 roku. 